\author{
Zygmunt Kawecki \\ Liceum Ogólnokształcące Nr 28 \\ im. Jana Kochanowskiego, Warszawa
}

\title{
Ranga przedmiotu podstawy przedsiębiorczości w edukacji szkolnej
}

Od kilku lat w szkołach ponadgimnazjalnych pojawił się przedmiot podstawy przedsiębiorczości. Warto rozważyć jego rolę i miejsce w edukacji szkolnej. Zajmę się krótko trzema problemami:

- rangą przedmiotu podstawy przedsiębiorczości w szkołach średnich,

- metodyką nauczania przedsiębiorczości w szkole,

- rolą nauczyciela przedmiotu podstawy przedsiębiorczości.

Opisując rangę nauczania przedmiotu podstawy przedsiębiorczości warto odnieść się do ostatnich danych Szwajcarskiego Instytutu Kształcenia Managerów IMD, upowszechnionych przez Instytut Funkcjonowania Gospodarki Narodowej przy Szkole Głównej Handlowej w Warszawie. Z badań prowadzonych przez Szwajcarski Instytut wynika, że wiedza ekonomiczna w naszym kraju jest niedostateczna. Jesteśmy ekonomicznymi analfabetami, ponieważ w rankingu pięćdziesięciu badanych państw lokujemy się w drugiej połowie piątej dziesiątki. Jeśli wiedza ekonomiczna całego polskiego społeczeństwa jest tak znikoma, z dużym prawdopodobieństwem oznacza to, że demagodzy, którzy obejmuję władzę, sami nie rozumieją ekonomii. A jeśli nawet posiadają wiedzę ekonomiczną, to nie są rozumiani przez społeczeństwo. W tej sytuacji niezwykle ważny jest fakt, że przedsiębiorczość została wprowadzona do szkół. Pozwoli to młodemu pokoleniu na zdobycie podstaw teoretycznych i niezbędnych umiejętności praktycznych w zakresie tego przedmiotu oraz wpłynie na kształtowanie przedsiębiorczej postawy bardzo przydatnej w życiu. Z powyższego tylko powodu ranga przedmiotu podstawy przedsiębiorczości powinna być wysoka.

Ponadto na rangę przedmiotu w sposób zasadniczy wpływa reakcja uczelni ekonomicznych na pojawienie się przedsiębiorczości w oświacie. Na przykład prestiżowa uczelnia Szkoła Główna Handlowa w Warszawie postanowiła w 2005 roku wprowadzić egzamin wstępny z przedsiębiorczości dla kandydatów ubiegających się o indeks. Decyzja ta była przedmiotem dyskusji nauczycieli akademickich i licealnych na pierwszym ogólnopolskim Forum Nauczycieli Przedsiębiorczości i Edukacji Ekonomicznej, które odbyło się w SGH 20 września 2004 r. Nauczyciele liceów są bardzo zainteresowani testem z przedsiębiorczości, zwłaszcza że kandydat, ubiegający się o indeks na SGH, może zdobyć w tym teście aż $20 \%$ ogólnej liczby punktów do zdobycia.

$\mathrm{Z}$ jednej strony fakt, że przedsiębiorczość nie jest jeszcze przedmiotem obowiązującym na egzaminie maturalnym obniża rangę tego przedmiotu, ale $\mathrm{z}$ drugiej strony egzamin $\mathrm{w}$ SGH bardzo ją podnosi. Sytuacja ta ma wpływ na praktyczne działania nauczyciela, szukającego właściwych sposobów dopasowania programów nauczania do potrzeb uczniów. W każdej klasie są przecież uczniowie, których interesuje wiedza ogólna w tym zakresie, jak i kandydaci na studia ekonomiczne. 
Test z przedsiębiorczości w $60 \%$ będzie dotyczył wiedzy z tego przedmiotu, w $20 \%$ sprawdzi rozumienie podstawowych pojęć ekonomicznych, a w kolejnych $20 \%$ będzie dotyczył umiejętności zastosowania tych pojęć w życiu.

Wobec powyższych informacji powstaje pytanie: czy uczyć bardziej ekonomii czy przedsiębiorczości? To z kolei rodzi dylemat: czy uczyć bardziej teorii czy praktyki? W konsekwencji rodzi się kolejne pytanie: czy jeszcze rozmawiamy o ekonomii, czy już o przedsiębiorczości, i w końcu pytanie: czy przedsiębiorczość to jest postawa w życiu, czy przedmiot, będący elementem programu szkół średnich. Staje się oczywiste, że test z przedsiębiorczości jako element rekrutacji na uczelnię w roku 2005 nadaje temu przedmiotowi nowe oblicze.

Jest to poważne zadanie dla nauczycieli i wydawców materiałów dydaktycznych. Dobrym rozwiązaniem byłyby zajęcia szkolne, podczas których należy uczyć młodzież postawy przedsiębiorczej zaś przygotowanie do egzaminu powinno odbywać się jako przedmiot dodatkowych zajęć fakultatywnych. Zarówno treści, jak i metody stosowane podczas jednych i drugich zajęć powinny być zróżnicowane.

Z moich obserwacji wynika, że uczniowie bardzo cenią sobie wiedzę praktyczną, którą zawiera program nauczania przedsiębiorczości. Zadaniem nauczyciela jest wypracowanie metod nauczania, które przyciągną uwagę przeciętnego ucznia i w konsekwencji zmuszą do aktywnego udziału w zajęciach. Generalnie brakuje zarówno gotowych ćwiczeń, jak i pomocy dydaktycznych, które można wykorzystać na lekcjach przedsiębiorczości. Do takich pomocy można zaliczyć filmy video, różnorodne gry symulujące procesy ekonomiczne czy programy multimedialne. Na rynku jest wiele podręczników do przedsiębiorczości, ale brakuje do nich obudowy w postaci atrakcyjnych pomocy dydaktycznych. Ciągle liczą się autorskie pomysły nauczyciela. Kreatywny nauczyciel szybko uczy się stosowania różnorodnych aktywnych metod nauczania, które mobilizują uwagę ucznia na lekcji i zachęcają do wyrażania własnej opinii. Jest wiele tematów, które można poprowadzić, używając nowoczesnych technik, takich jak multimedia i Internet.

Stworzenie witryny internetowej dla uczniów i nauczycieli przedsiębiorczości, dla przykładu „Przedsiębiorczość w liceum” mogłoby bardzo pomóc w wymianie sprawdzonych rozwiązań dydaktycznych. Pozytywne doświadczenia ma w tym zakresie Stowarzyszenie Nauczycieli Przedsiębiorczości. Organizuje ono szkolenia doskonalące umiejętności nauczycieli tego przedmiotu.

Nauczanie „przedsiębiorczości” napotyka rozmaite bariery, między innymi: brak materiałów dydaktycznych, brak rozumienia potrzeby kształcenia postawy przedsiębiorczej wśród dyrektorów, uczniów i rodziców, którzy nie doceniają treści jaką niesie przedmiot, może wynikać to $\mathrm{z}$ faktu, że jako naród przetrwaliśmy i dawaliśmy sobie radę pod zaborami, okupacją oraz $\mathrm{w}$ poprzednim systemie gospodarki centralnie sterowanej, czyli byliśmy przedsiębiorczy. Obecne wyzwania cywilizacyjne wymagają jednak zupełnie innych zachowań przedsiębiorczych opartych na wiedzy merytorycznej i praktycznej. Dlatego też należy zastanowić się nad stylem pracy i własną postawą nauczyciela przedsiębiorczości, który powinien być wzorem postawy przedsiębiorczej w warunkach szkolnych. Powinien to być nauczyciel kreatywny i poszukujący. Nauczyciel nie uczestniczy jednak bezpośrednio w procesach zachodzących w gospodarce. Konieczne jest więc wsparcie biznesu i władz lokalnych. Współpraca pomiędzy podmiotami aktywnymi w gospodarce a edukacją może odbywać się za pośrednictwem nauczyciela przedsiębiorczości. Warto tu wspomnieć, że promowanie przedsiębiorczości i rozwijanie współpracy między biznesem i edukacją jest jednym z celów strategii lizbońskiej przyjętej do realizacji w Unii Europejskiej do 2010 roku.

Nauczyciel przedsiębiorczości powinien pełnić rolę szkolnego doradcy, który będzie pomagał w wyborze kierunków studiów oraz wskazywał te $\mathrm{z}$ nich, w których uczniowie odnajdą swoją przyszłość.

Konferencje, warsztaty i szkolenia organizowane z myślą o nauczycielach przedsiębiorczości przyczyniają się do podniesienia wiedzy nauczyciela podstaw przedsiębiorczości 
oraz nadania odpowiedniej rangi samemu przedmiotowi. Miejmy nadzieję, że absolwent szkoły średniej nie będzie musiał się wstydzić faktu, że jest po prostu nie umiejącym sobie radzić w życiu ekonomicznym analfabetą.

Na zakończenie warto podkreślić rolę Stowarzyszenia Nauczycieli Przedsiębiorczości, które zapewnia nauczycielom tego przedmiotu wymianę doświadczeń.

Stowarzyszenie zostało zarejestrowane jesienią 2003 roku. Prezesem Stowarzyszenia jest Pani Joanna Grącka, a członkami są nauczyciele przedsiębiorczości ${ }^{1}$ i wiedzy ekonomicznej z całej Polski i ich liczba ciągle wzrasta. Więcej informacji wraz z adresem siedziby Stowarzyszenia oraz adresami poczty elektronicznej do władz Stowarzyszenia znajdują się na stronie internetowej www.nauczyciele.org .

${ }^{1} \mathrm{~W}$ tym Autor artykułu (przyp. red. ) 